\title{
Uji Resistensi Antibiotik Staphylococcus aureus Isolat Kolam Renang
}

\author{
Antibiotic Resistance Test of Staphylococcus aureus Isolates in Swimming Pools
}

\author{
Makhabbah Jamilatun ${ }^{*}$ \\ Jurusan Analis Kesehatan Poltekkes Kemenkes Banten, \\ J1. Dr. Sitanala, Neglasari, Kota Tangerang, Banten \\ *Corresponding author: makhabbah.j@gmail.com
}

Received: February 30, 2019; Revise: April 15, 2019; Accepted: May 7, 2019

DOI: https://doi.org/10.31001/biomedika.v12i1.462

\begin{abstract}
ABSTRAK
Salah satu bakteri yang telah mengkontaminasi kolam renang di Kota Tangerang adalah bakteri Staphylococcus aureus. Penelitian ini dilakukan dengan tujuan untuk mengetahui resistensi bakteri Staphylococcus aureus isolat kolam renang Kota Tangerang terhadap antibiotik. Penelitian diawali dengan isolasi $S$. aureus dari kolam renang Kota Tangerang yang dilakukan dengan media selektif MSA (Manitol Salt Agar), dilanjutkan dengan pewarnaan gram, uji katalase serta uji koagulase. Uji resistensi antibiotik dilakukan menggunakan metode difusi cakram Kirby Bauer sesuai rekomendasi Clinical Laboratory Standards Institute (CLSI). Sebanyak 12 isolat S. aureus Kolam Renang Kota Tangerang diuji resistensinya terhadap lima jenis antibiotik, yaitu AMP (amphycillin) $(10 \mu \mathrm{g})$, CIP (ciprofloxacin) $(5 \mu \mathrm{g})$, TET (tetracycline) $(30 \mu \mathrm{g})$, OXA (oxacillin) $(1 \mu \mathrm{g})$, dan FOS (fosfomycin) $(200 \mu \mathrm{g})$. Hasil penilitian menunjukkan bahwa bakteri Staphylococcus aureus isolat kolam renang Kota Tangerang memiliki resistensi yang berbeda terhadap antibiotik. Semua isolat Staphylococcus aureus yang diuji bersifat sensitif antibiotik amphycillin, ciprofloxacin, tetracycline, oxacillin. Sedangkan terhadap antibiotik fosfomycin, terdapat 8 isolat yang bersifat resisten dan 4 isolat yang bersifat sensitif.
\end{abstract}

Kata kunci: resistensi; antibiotik; Staphylococcus aureus

\section{ABSTRACT}

One of the bacteria contaminating many swimming pools in Tangerang is Staphylococcus aureus. This research is conducted to identify the resistance of Staphylococcus aureus isolates found in swimming pools in Tangerang to antibiotic. The research was started with isolation of $\mathrm{S}$. aureus from swimming pools in Tangerang using a selective medium of MSA (Manitol Salt Agar), followed by gram staining, catalase test and coagulase test. Antibiotic resistance test was performed using KirbyBauer disk diffusion method based on the recommendation of Clinical Laboratory Standards Institute (CLSI). As many as 12 isolates of S. aureus found in swimming pools in Tangerang were tested on five

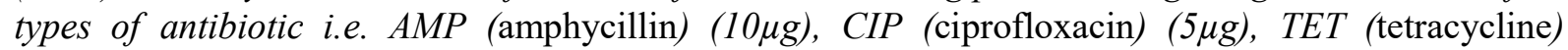

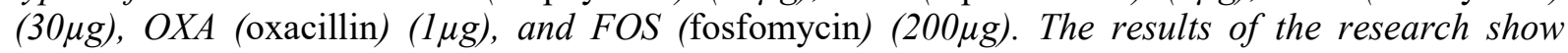
Staphylococcus aureus isolates found in swimming pools in Tangerang has varying degree of resistance to antibiotic. All the tested Staphylococcus aureus isolates are sensitive to amphycillin, ciprofloxacin, tetracycline, and oxacillin. Moreover, there are 8 isolates resistant to fosfomycin and 4 isolates sensitive to fosfomycin.

Keywords: resistance; antibiotic; Staphylococcus aureus 


\section{PENDAHULUAN}

Kolam renang merupakan fasilitas umum yang dapat digunakan sebagai tempat rekreasi dan wahana berolahraga. Air yang digunakan untuk mengisi kolam renang itu sendiri seringkali terkontaminasi mikroorganisme termasuk bakteri yang berhabitat asli dalam badan air ataupun berasal dari kontaminasi lingkungan di sekitarnya. Beberapa spesies mikroorganisme tersebut dapat berperan sebagai patogen opportunistik pada manusia. Dalam penelitian yang dilakukan oleh Aminah dan Jamilatun (2017), diperoleh hasil bahwa telah ditemukan bakteri kontaminan di Kolam Renang Kota Tangerang, salah satu bakteri tersebut adalah Staphylococcus aureus.

Staphylococcus aureus (S. aureus) merupakan bakteri gram positif patogen yang dapat menyebabkan berbagai penyakit (Flora, 2013). Pada saat sistem imun menurun maka bakteri ini akan masuk ke dalam tubuh baik melalui mulut, inhalasi, maupun penetrasi kulit. Jika bakteri ini masuk ke dalam peredaran darah dan menyebar ke organ tubuh lainnya maka akan merusak organ-organ tubuh dan menyebabkan berbagai penyakit (Irianto, 2014). Telah diketahui bahwa $S$. aureus menyebabkan jerawat (Adekunle et al., 2010) dan berpotensi menyebabkan sepsis luka pasca-operasi (Ako-Nai et al., 2005). Staphylococcus aureus juga dapat menyebabkan sejumlah penyakit infeksi pada manusia, antara lain infeksi kulit ringan, bakteremia, penyakit sistemik, meningitis, endocarditis, osteomielitis, serta keracunan makanan (Westh et al., 2004 dan Lee et al., 2003).

Terapi atau pengobatan terhadap infeksi bakteri patogen dilakukan dengan antibiotik. Sejak ditemukannya, antibiotik telah digunakan secara luas untuk mengurangi angka kematian yang disebabkan oleh penyakit infeksi (Inglis, 2004). Namun dalam perkembanganya, penggunaan antibiotik tidak selalu didasarkan pada hasil kultur kuman penyebab infeksi. Sehingga meningkatkan pemakaian antibiotik tanpa aturan yang jelas pada akhirnya menyebabkan penggunaan antibiotik yang tidak rasional (Adekunle et al., 2010). Selain itu, tidak terkendalinya penggunaan antibiotik cenderung akan meningkatkan resistensi bakteri yang semula sensitif (Refdanita et al., 2004).

Antibiotik adalah sekelompok senyawa yang bekerja dengan cara menghambat pertumbuhan bakteri (bakteriostatik) atau menyebabkan kematian bakteri (bakterisidal) (Pratiwi, 2008). Dengan adanya mekanisme kerja antibiotik terhadap bakteri maka bakteri juga mengadakan perlawanan. Sehingga penggunaan antibiotik secara berlebihan dapat menimbulkan tekanan selektif yang mendorong perkembangbiakan mikroorganisme yang resisten (Yenny dan Herwana, 2007).

Beberapa penelitian melaporkan bahwa $S$. aureus telah mengalami resistensi terhadap beberapa antibiotik. Penelitian yang dilakukan oleh Adekunle et al. (2010), isolat $S$. aureus yang berasal dari jerawat telah resisten terhadap beberapa antibiotik, diantaranya ampicillin, erythromycin, cloxacillin, cotrimoxazole, streptomycin dan penicillin. Penelitian yang dilakukan oleh Beyene (2016), melaporkan bahwa isolat $S$. aureus yang berasal dari susu sapi telah resisten terhadap antibiotik penicillin, ampicillin, 
amoxicillin, dan trimethoprim- sulpha methoxazole. Adanya resistensi terhadap antibiotik tersebut menyebabkan pengobatan infeksi yang disebabkan oleh $S$. aureus semakin sulit karena munculnya strain resistant multidrug (Ako-Nai et al., 2005).

Resistensi antibiotik merupakan permasalahan penting dalam pengobatan (Gootz, 2010). Penggunaan antibiotik dengan justifikasi yang kurang tepat dapat mengakibatkan resistensi obat, meningkatkan morbiditas, mortalitas dan biaya pengobatan (Sujith, 2012). Hal ini bisa dihindari dengan penggunaan yang bijaksana dan rasional dari antibiotik yang ada (Kumar, 2013). Sehingga perlu dilakukan uji sensitivitas antibiotik terlebih dahulu sebelum memberikan suatu antibiotik untuk dapat meminimalisir terjadinya resistensi yang mengarah pada multidrugs resistance. Adanya resistensi bakteri terhadap antibiotik serta perkembangannya yang sangat dipengaruhi oleh intensitas pemaparan antibiotik di suatu wilayah, mendorong dilakukannya penelitian untuk mengkaji resistensi bakteri yang diisolasi dari kolam renang sebagai tempat yang berpotensi menjadi sumber kontaminan bagi perenang. Berdasarkan latar belakang tersebut maka penelitian dilakukan dengan tujuan mengetahui resistensi bakteri Staphylococcus aureus isolat kolam renang Kota Tangerang terhadap antibiotik.

\section{METODE PENELITIAN}

\section{Alat dan Bahan}

Peralatan yang digunakan antara lain lampu spirtus, inkubator, autoclave, ose bulat, ose tusuk, oven, hot plate, batang pengaduk, botol semprot, gelas kimia, labu, kaca objek dan kaca penutup, tabung reaksi, rak tabung reaksi, alumunium foil, karet, tusuk gigi, bunsen burner, korek api, tissue, mikroskop, immersion oil, spatula, stirrer, lampu Bunsen, kapas steril, kertas kopi, kain kassa, tabung reaksi, pipet mikropipet dan tip, botol sampel.

Bahan-bahan yang digunakan meliputi sampel air, MSA, Mueller Hinton $\operatorname{Agar}(\mathrm{MH})$, kristal violet, iodium (lugol), alkohol 95\%, safranin, spiritus, alkohol $70 \%$, aquades, cakram antibiotik ciprofloxacin (CIP) $(5 \mu \mathrm{g})$, tetracycline (TET) $(30 \mu \mathrm{g})$, amphycillin (AMP) $(10 \mu \mathrm{g})$, oxacillin (OXA) $(5 \mu \mathrm{g})$, fosfomycin (FOS) $(200 \mu \mathrm{g})$.

\section{Pengambilan sampel}

Pengambilan sampel dilakukan dengan cara air dari kolam renang dimasukkan ke dalam botol steril sebanyak $100 \mathrm{ml}$ secara aseptis. Kemudian sampel ditempatkan dalam wadah botol dan dibawa ke Laboratorium Mikrobiologi Jurusan Analis Kesehatan Poltekkes Kemenkes Banten.

\section{Isolasi dan Identifikasi Staphylococcus aureus}

Sampel air sebanyak $0,1 \mathrm{~mL}$ dipipet dengan menggunakan pipet ukur ke dalam medium MSA dengan metode tuang. Lalu diratakan dengan menggunakan batang segitiga pada permukaan plate MSA. Cawan petri yang sudah ditanami sampel, dibungkus dengan kertas kopi dan dimasukkan ke dalam inkubator. Sampel diinkubasi pada suhu $37^{\circ} \mathrm{C}$ selama 24 jam. Selanjutnya koloni yang tumbuh dilakukan pemeriksaan makroskopis berupa koloni berwarna kuning dan secara mikroskopis dengan teknik pewarnaan Gram berupa bakteri bulat berwarna ungu (batang Gram 
positif). Dilanjutkan dengan uji katalase dan koagulase. Uji katalase, dilakukan dengan mengambil satu koloni dari media MSA menggunakan ose dan ditambahkan $\mathrm{H}_{2} \mathrm{O}_{2} 3 \%$. Kemudian dilihat ada tidaknya gelembung, apabila terdapat gelembung maka diduga tersangka Staphylococcus aureus. Uji koagulase, dilakukan dengan mengambil satu koloni dari media MSA menggunakan ose dan ditambahkan dengan plasma sitrat. Kemudian dilihat ada tidaknya butiran seperti pasir/gumpalan apabila terdapat butiran seperti pasir/gumpalan maka diduga tersangka Staphylococcus aureus.

\section{Uji Resistensi Antibiotik}

Uji kerentanan antibiotik isolat Staphylococcus aureus dilakukan dengan metode difusi cakram Kirby Bauer sesuai dengan rekomendasi Clinical Laboratory Standards Institute (CLSI). Satu koloni bakteri disuspensikan ke dalam $5 \mathrm{ml} \mathrm{NaCl}$ $0,9 \%$ steril. Selanjutnya disetarakan dengan suspensi bakteri dengan Turbidity Standard McFarland 0,5. Suspensi bakteri ini diusapkan dengan perlahan pada seluruh permukaan lempeng agar MuellerHilton sampai rata dengan menggunakan kapas lidi steril. Cakram antibiotik diletakkan secara aseptik di atas permukaan lempeng agar kemudian diinkubasi pada suhu $37{ }^{\circ} \mathrm{C}$ selama $18-24$ jam. Setelah diinkubasi daerah di sekitar cakram yang tidak ditumbuhi bakteri diukur dengan menggunakan penggaris. Pembacaan dan evaluasi kepekaan mengikuti petunjuk CLSI.

\section{Analisis Data}

Data yang diperoleh dari penelitian ini dianalisis secara deskriptif dan ditampilkan dalam bentuk Tabel dan Gambar. Pembacaan dan evaluasi kepekaan mengikuti petunjuk CLSI (2014).

\section{HASIL DAN PEMBAHASAN}

Diameter zona hambat bakteri Staphylococcus aureus diuji kepekaan terhadap antibiotik dan hasil tersebut dapat dilihat pada Tabel 1.

Tabel 1. Diameter Zona Hambat (mm) Staphylococcus aureus Isolat Kolam Renang Kota Tangerang

\begin{tabular}{|c|c|c|c|c|c|c|c|c|c|c|}
\hline \multirow[t]{4}{*}{ Isolat } & \multicolumn{10}{|c|}{ ANTIBIOTIK } \\
\hline & \multicolumn{2}{|c|}{ AMP } & \multicolumn{2}{|c|}{ CIP } & \multicolumn{2}{|c|}{ TET } & \multicolumn{2}{|c|}{ OXA } & \multicolumn{2}{|c|}{ FOS } \\
\hline & Diameter & & Diameter & & Diameter & & Diameter & & Diameter & \\
\hline & $\begin{array}{c}\text { Zona } \\
\text { Hambat } \\
(\mathbf{m m})\end{array}$ & $\mathbf{S} / \mathbf{I} / \mathbf{R}$ & $\begin{array}{c}\text { Zona } \\
\text { Hambat } \\
(\mathbf{m m})\end{array}$ & $\mathbf{S} / \mathbf{I} / \mathbf{R}$ & $\begin{array}{c}\text { Zona } \\
\text { Hambat } \\
(\mathbf{m m})\end{array}$ & $\mathbf{S} / \mathbf{I} / \mathbf{R}$ & $\begin{array}{c}\text { Zona } \\
\text { Hambat } \\
(\mathbf{m m})\end{array}$ & $\mathbf{S} / \mathbf{I} / \mathbf{R}$ & $\begin{array}{c}\text { Zona } \\
\text { Hambat } \\
(\mathbf{m m})\end{array}$ & $\mathbf{S} / \mathbf{I} / \mathbf{R}$ \\
\hline 1 & 23 & $\mathrm{~S}$ & 33 & $\mathrm{~S}$ & 32 & $\mathrm{~S}$ & 25 & $\mathrm{~S}$ & 0 & $\mathrm{R}$ \\
\hline 2 & 25 & $\mathrm{~S}$ & 34 & $\mathrm{~S}$ & 33 & $\mathrm{~S}$ & 25 & S & 0 & $\mathrm{R}$ \\
\hline 3 & 23 & $\mathrm{~S}$ & 32 & $\mathrm{~S}$ & 30 & $\mathrm{~S}$ & 25 & S & 0 & $\mathrm{R}$ \\
\hline 4 & 23 & $\mathrm{~S}$ & 31 & S & 30 & $\mathrm{~S}$ & 22 & $\mathrm{~S}$ & 0 & $\mathrm{R}$ \\
\hline 5 & 22 & $\mathrm{~S}$ & 33 & $\mathrm{~S}$ & 30 & $\mathrm{~S}$ & 23 & $\mathrm{~S}$ & 0 & $\mathrm{R}$ \\
\hline 6 & 22 & $\mathrm{~S}$ & 31 & $\mathrm{~S}$ & 30 & $\mathrm{~S}$ & 25 & $\mathrm{~S}$ & 0 & $\mathrm{R}$ \\
\hline 7 & 22 & $\mathrm{~S}$ & 30 & $\mathrm{~S}$ & 28 & $\mathrm{~S}$ & 20 & $\mathrm{~S}$ & 0 & $\mathrm{R}$ \\
\hline 8 & 25 & $\mathrm{~S}$ & 31 & $\mathrm{~S}$ & 30 & $\mathrm{~S}$ & 28 & $\mathrm{~S}$ & 30 & $\mathrm{~S}$ \\
\hline 9 & 28 & $\mathrm{~S}$ & 30 & $\mathrm{~S}$ & 30 & $\mathrm{~S}$ & 26 & $\mathrm{~S}$ & 30 & $\mathrm{~S}$ \\
\hline 10 & 40 & $\mathrm{~S}$ & 31 & $\mathrm{~S}$ & 28 & $\mathrm{~S}$ & 30 & $\mathrm{~S}$ & 0 & $\mathrm{R}$ \\
\hline 11 & 20 & $\mathrm{~S}$ & 30 & $\mathrm{~S}$ & 27 & $\mathrm{~S}$ & 29 & $\mathrm{~S}$ & 43 & $\mathrm{~S}$ \\
\hline 12 & 22 & $\mathrm{~S}$ & 33 & $\mathrm{~S}$ & 31 & $\mathrm{~S}$ & 30 & $\mathrm{~S}$ & 45 & $\mathrm{~S}$ \\
\hline Rata2 & 25 & $\mathrm{~S}$ & 32 & $\mathrm{~S}$ & 30 & $\mathrm{~S}$ & 26 & $\mathrm{~S}$ & - & - \\
\hline
\end{tabular}


Zona hambat yang terbentuk dari hasil uji resistensi $S$. aureus Isolat Kolam Renang Kota Tangerang terhadap antibiotik pada media agar Mueller-Hilton dapat dilihat pada Gambar 1.

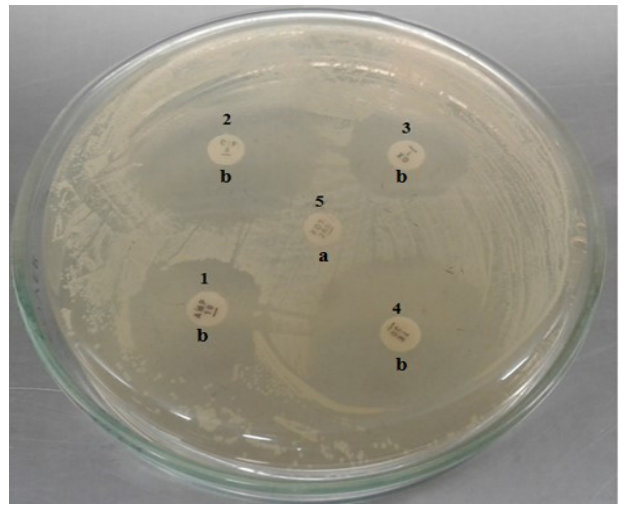

Gambar 1. Zona hambat $S$. aureus Isolat Kolam Renang Kota Tangerang terhadap antibiotik pada media Mueller-Hilton Agar. Antibiotik yang digunakan: 1-AMP (amphycillin), 2-CIP (ciprofloxacin), 3TET (tetracycline), 4-OXA (oxacillin), 5- FOS (fosfomycin). Menunjukkan tidak terbentuknya zona hambat atau zona hambat yang sempit dari antibiotik pada biakan bakteri $S$. aureus Isolat Kolam Renang Kota Tangerang, yang berarti bahwa bakteri tersebut telah resisten terhadap antibiotik yang diuji. Menunjukkan terbentuknya zona hambat antibiotik pada biakan bakteri $S$. aureus Isolat Kolam Renang Kota Tangerang, yang berarti bahwa bakteri tersebut masih sensitif terhadap antibiotik yang diuji. Makin luas zona hambat yang terbentuk, maka makin sensitif bakteri tersebut terhadap antibiotik yang diuji.

Hasil uji resistensi $S$. aureus Isolat Kolam Renang Kota Tangerang yang tersaji pada Tabel 1. menunjukkan bahwa diantara semua isolat yang diuji bersifat sensitif terhadap antibiotik amphycillin, ciprofloxacin, tetracycline, dan oxacillin. Hasil ini berbeda dengan beberapa penelitian sebelumnya bahwa Isolat $S$. aureus telah resisten terhadap amphycillin (Wagner et. al., 2005), resisten terhadap ciprofloxacin (Bhavya et.al., 2014), resisten terhadap tetrasiklin (Farhat et al., 2012). Penelitian yang dilakukan oleh Mihaela et.al. (2010), juga menunjukkan bahwa $S$. aureus telah resisten terhadap sebagian besar antibiotik, seperti $\beta$-lactams (ampicillin, oxacillin), aminoglycosides (gentamicin, kanamycin), macrolides (erythromycin) dan tetracyclines (tetracycline).

Sedangkan terhadap antibiotik fosfomycin, diantara 12 bakteri S. aureus Isolat Kolam Renang Kota Tangerang terdapat 4 isolat yang bersifat sensitif dan 8 isolat yang bersifat resisten. Hasil ini sesuai dengan penelitian yang dilakukan oleh Zhuyingjie et al., (2016), yang melaporkan bahwa isolat MRSA telah resisten terhadap fosfomycin dan diketahui terdapat gen yang bertanggung jawab terhadap resistensi tersebut, yaitu gen fos B.

Resistensi bakteri terhadap antibiotik adalah kemampuan alamiah bakteri untuk mempertahankan diri terhadap efek antibiotik dengan menetralisir dan melemahkan daya kerja antibiotik (Giedraitiene et.al., 2011). Pada umumnya, resistensi dapat terjadi melalui beberapa cara. Resistensi dapat terjadi inherent atau intrinsik (yang menjadi sifatnya) sehingga sejak kemunculan bakteri tersebut tidak pernah sensitif terhadap antibiotik tertentu. Resistensi intrinsik dapat berhubungan dengan kurangnya afinitas obat pada target kerja bakteri, tidak tersedianya akses obat 
ke dalam sel bakteri, ekstrusi obat secara kromosomal, dan produksi alamiah enzimenzim yang menginaktivasi antibiotik (Cox, 2014). Selain itu, resistensi dapat terjadi secara acquired atau didapat melalui suatu proses mutasi atau transfer genetik. Ditambahkan oleh Furuya dan Lowy (2006), timbulnya resistensi bakteri patogenik terhadap antibiotik dapat disebabkan oleh pemakaian antibiotik yang kurang tepat, dosis yang rendah dan jangka waktu yang lama.

Berdasarkan hasil penelitian ini, diketahui bahwa $S$. aureus Isolat Kolam Renang Kota Tangerang masih sensitif terhadap empat antibiotik dengan rata-rata diameter zona hambat: $25 \mathrm{~mm}$ untuk amphycillin, $32 \mathrm{~mm}$ untuk ciprofloxacin, $30 \mathrm{~mm}$ untuk tetracycline, $26 \mathrm{~mm}$ untuk oxacillin. Antibiotik paling efektif digunakan untuk pengobatan adalah ciprofloxacin karena memiliki zona hambat terluas. Sedangkan fosfomycin, meskipun telah diketahui bahwa fosfomycin merupakan antibiotik yang memiliki spektrum luas, aktif melawan bakteri Gram positif dan bakteri Gram negatif (Falagas et al., 2010 dan Oteo et. al., 2010). Namun dalam penelitian ini, beberapa isolat sudah mengalami resistensi sehingga fosfomycin kurang efektif digunakan untuk pengobatan.

Ditemukannya bakteri patogenik yang resisten terhadap antibiotik mempunyai arti penting bagi kesehatan masyarakat, karena dapat mengakibatkan kegagalan pengobatan pada manusia, naiknya waktu rawat inap di Rumah Sakit, meningkatkan biaya pengobatan, dan meninggalkan residu antibiotik (Tjaniadi et al., 2003). Beberapa penelitian mengenai sensitifitas isolat $S$. aureus terhadap antibiotik menunjukkan hasil yang berbeda. Hal ini membuktikan bahwa pola sensitifitas isolat bakteri penyebab penyakit infeksi berbeda antara satu daerah dengan daerah yang lain. Selain itu, habitat dan sumber $S$. aureus yang berbeda memungkinkan karakter senfitifitas terhadap antibiotik yang berbeda. Sesuai dengan pernyataan Bhavya et al., (2014) bahwa sensitivitas suatu antibiotik tergantung dari sifat genetik isolat bakteri dan lingkungan tempat hidupnya. Ditambahkan pula oleh Rajaduraipandi et al. (2006), bahwa sifat resistensi bakteri terhadap antibiotik di suatu wilayah sangat bervariasi.

Selain itu, peningkatan kejadian resistensi bakteri terhadap antibiotik bisa terjadi dengan 2 cara. Pertama, Mekanisme Selection Pressure. Jika bakteri resisten tersebut berbiak secara duplikasi setiap 2030 menit (untuk bakteri yang berbiak cepat), maka dalam 1-2 hari, seseorang tersebut dipenuhi oleh bakteri resisten. Jika seseorang terinfeksi oleh bakteri yang resisten, maka upaya penanganan infeksi dengan antibiotik semakin sulit. Kedua, Penyebaran resistensi ke bakteri yang nonresisten melalui plasmid. Hal ini dapat disebarkan antar bakteri sekelompok maupun dari satu orang ke orang lain (Menkes (2011), KPRA (2016)). Sehingga diperlukan strategi pencegahan peningkatan bakteri resisten, yang antara lain dapat dilakukan dengan dua cara, pertama dengan menggunakan antibiotik secara bijak dan kedua dengan meningkatkan ketaatan terhadap prinsipprinsip kewaspadaan standar sebagai upaya pencegahan penyebaran bakteri resisten melalui plasmid (Menkes (2011), KPRA (2016)). 
Adanya perbedaan tingkat resistensi bakteri $S$. aureus terhadap beberapa antibiotik pada wilayah geografi yang berbeda, menunjukkan bahwa uji resistensi antibiotik sangat penting dalam menentukan antibiotik yang tepat sehingga regimen pengobatan yang berbeda pada masing-masing daerah bisa tersedia dengan tepat.

\section{KESIMPULAN}

Bakteri Staphylococcus aureus isolat kolam renang Kota Tangerang memiliki resistensi yang berbeda terhadap antibiotik. Semua isolat Staphylococcus aureus yang diuji bersifat sensitif antibiotik amphycillin, ciprofloxacin, tetracycline, oxacillin. Sedangkan terhadap antibiotik fosfomycin, terdapat 8 isolat yang bersifat resisten dan 4 isolat yang bersifat sensitif.

\section{DAFTAR PUSTAKA}

Adekunle, O.A., Adesola, A.A., Akintunde and Patrick, O.O. 2010. Antibiotics resistance and susceptibility pattern of a strain of Staphylococus aureus associated with acne. International Journal of Medicine and Medical Sciences 2(9), pp. 277-280.

Ako-Nai AK, Adeyemi, F.M., Aboderin, O.A., Kassim, O.O. 2005. Antibiotic resistance profile of staphylococci from clinical sources recovered from infants. African Journal of Biotechnology Vol. 4 (8), pp. 816-822, August 2005.

Aminah, A., \& Jamilatun, M. 2017. Kualitas Biologis Air Kolam Renang Umum di Kota Tangerang. Jurnal Ilmu dan Teknologi Kesehatan, 4(2), 205-213. https://doi.org/10.32668/jitek.v4i2.84

Bhavya C., Prabhakara, S., Nagaraj,S., Etienne, J., Arakere, G. 2014. High Prevalence of Ciprofloxacin Resistance in Community Associated Staphylococcus aureus in a Tertiary Care Indian Hospital. Advances in Microbiology, 2014, 4, 133-141.
Beyene, G.F. 2016. Antimicrobial Susceptibility of Staphylococcus aureus in Cow Milk, Afar Ethiopia. International Journal of Modern Chemistry and Applied Science 2016, 3(1),280-283

Cox, G., Wright, G.,D. 2013. Intrinsic Antibiotic Resistance: Mechanism, Origins, Challenges and Solutions. Int $\mathrm{J}$ Med Microbiol. 303(6-7):287-92.

Falagas, M.E, Kastoris, A.C, Kapaskelis, A.M. 2010. Fosfomycin for the treatment of multidrug-resistant, including extended spectrum beta-lactamase producing Enterobacteriaceae infections: A systematic review. Lancet Infect Dis10:4350.

Farhat, U., Malik, S.A., Ahmed, J., Ullah, F., Shah, S.M., Ayaz, M., Hussain, S and Khatoon, L. 2012. Investigation of the Genetic Basis of Tetracycline Resistance in Staphylococcus aureus from Pakistan. Tropical Journal of Pharmaceutical Research 11 (6): 925-931.

Flora Grace M. 2013. D-Test for Detection of Antimicrobial Susceptibility in Methicillin Resistant Staphylococcus Aureus (MRSA). IOSR Journal of Pharmacy and Biological Sciences (IOSR-JPBS) e-ISSN: 2278-3008, p-ISSN:2319-7676. Volume 7, Issue 3 (Jul. - Aug. 2013), PP 32-35 www.iosrjournals.org.

Furuya, E.Y. and Lowy, F.D. 2006. Antimicrobial resistance bacteria in the community setting. Nature Reviews 4, 36-45.

Giedraitienè, A., Vitkauskienè, A., Naginienè, R., Pavilonis, A. 2011. Antibiotic Resistance Mechanisms of Clinically Important Bacteria. Medicina (Kaunas) 2011;47(3):137-46.

Gootz, T. 2010. The global problem of antibiotic resistance. Crit Rev Immunol 30(1):79-93.

Inglis, T.J.J. 2003. Microbiology and Infection. 2nd Ed. Toronto. Churchill Livingstone.

Irianto, K. 2014. Bakteriologi, Mikologi, dan Virologi. Bandung: Alfabeta

KPRA (Komite Pengendalian Resistensi Antimikroba) 2016. Panduan Umum Penggunaan Antimikroba. RSUD Dr Saiful Anwar Malang.

Kumar, A.R. 2013. Antimicrobial Sensitivity Pattern of Staphylococcus aureus isolated from Pus Fromtertiary Care Hospital, Surendranagar, Gujarat and Issues Related 
to the Rational Selection of Antimicrobials. Scholars Journal of Applied Medical Sciences (SJAMS) ISSN 2320-6691. Sch. J. App. Med. Sci., 2013; 1(5):600-605.

Lee, J.H. 2003. Methicillin (oxacillin)-resistant Staphylococcus aureus strains isolated from major food animals and their potential transmission to humans. Appl. Environ. Microbiol. 69, 6489-6494.

Menteri Kesehatan RI. 2011. Pedoman Umum Penggunaan Antibiotik. Peraturan Menteri Kesehatan Republik Indonesia Nomor 2406/MENKES/PER/XII/2011.

Mihaela Brînda, V. Herman, B. Faur. 2010. Antimicrobial Sensitivity of Some Staphylococcus Aureus Strains from Bovine Mastitis. Lucrări Stiintifice Medicină Veterinară XLIII (1), 2010 Timisoara.

Oteo J, Bautista V, Lara N, et al. Parallel increase in community use of fosfomycin and resistance to fosfomycin in extendedspectrum betalactamase (ESBL)producing Escherichia coli. J Antimicrob Chemother 2010; 65:2459-63.

Pratiwi, S. 2008. Mikrobiologi Farmasi. Jakarta: Erlangga.

Rajaduraipandi, K. KR Mani, K Panneerselvam, M Mani, M Bhaskar, P Manikandan. 2006. Prevalence and Antimicrobial Susceptibility Pattern of Methicillin Resistant Staphylococcus Aureus: A Multicentre Study. Indian Journal of Medical Microbiology, (2006) 24 (1):34-8.

Refdanita, Maksum R, Nurgani A, Endang P. 2004. Pola Kepekaan Kuman Terhadap Antibiotik di ruang intensif Rumah Sakit
Fatmawati Jakarta Tahun 2001-2002. Jakarta: Makara Kesehatan vol.8(2).

Sujith , J. C. 2012. Consequenses of irrational use of Antibiotics. Indian $J$ Med Ethics 2012;4:1-2.

Tjaniadi, P., Lesmana, M., Subekti, D. Machpud, N. Komalarini, S., Santoso, W., Simanjuntak, C.H., Punjabi, N. Campbell, Jr., Alexander, WK and Oyofo, BA. 2003. Antimicrobial associated resistance of bacterial pathogens with diarrheal patients in Indonesia. Am. J. Trop. Med. Hyg. 68(6), 666-670.

Wagner L.C.B., Marcelo Fabiano Gomes BORIOLLO, Reginaldo Bruno GONÇALVES \& José Francisco HÖFLING. 2005. Staphylococcus aureus Ampicillin-Resistant From The Odontological Clinic Environment. Rev. Inst. Med. trop. S. Paulo 47(1):19-24, January-February, 2005.

Westh, H.; Zinn, C.S.; Rosdahl, V.T. 2004. An international multicenter study of antimicrobial consumption and resistance in Staphylococcus aureus isolates from 15 hospitals in 14 countries. Microb. Drug Resist. 2004, 10, 169-176.

Yenny dan Herwana E. 2007. Resistensi dari bakteri enterik: aspek global terhadap antimikroba. Universa Medicina. 26 (1). 46-56.

Zhuyingjie Fu, Yang Liu, Chunhui Chen, Yan Guo, Ying Ma, Yang Yang, Fupin $\mathrm{Hu}$, Xiaogang Xu, Minggui Wang. 2016. Characterization of Fosfomycin Resistance Gene, fosB, in Methicillin-Resistant Staphylococcus aureus Isolates. PLOS ONE | DOI:10.1371/journal.pone.0154829 May 4. 